\title{
KARAKTERISTIK DAN KONSEP PENDIDIKAN ISLAM YANG TERKANDUNG DALAM SURAH AL-A'RAF AYAT 179
}

\author{
Surawardi \\ Dosen Fakultas Tarbiyah dan Ilmu Keguruan IAIN Antasari Banjarmasin \\ Jalan A.Yani KM 4,5 Banjarmasin
}

\begin{abstract}
The problem in this research is how the concept of Islamic Education contained in Surah Al-Araf Verse 179. The aim of this study was to determine the concept of Islamic Education contained in Surah Al-Araf Verse 179. In Surah AlAraf verse 179, Allah describes bahwasannya who will be the inhabitants of hell are people neglect and do not use their sense their minds to understand the true nature of things, is unwilling to avail their eyes and ears either to conclude all who knew and took the sciences as well as to know the signs of God that is in his creation, and the signs of his greatness contained in his books that are both a cause and the perfection of faith into the soul urge to enhance one's Islam. Islamic educational values contained in Surah Al-Araf verse 179 includes: Hell Hell supplied For Jin and Man, people who have a sense / brain, people who have eyes, those who have ears, diumpakan like stars even worse again.
\end{abstract}

Keywords: Concepts, Islamic Education, Surah Al Araf Verse 179

\section{PENDAHULUAN}

Negara Indonesia adalah negara yang sedang giat-giatnya melaksanakan pembangunan dalam berbagai bidang dmi tercapainya cita-cita kemerdekaan yakni kehidupan yang makmur, merata, mental dan spritual. Salah satu pembangunan yang digalakkan pemerintah adalah pembangunan dalam bidang pendidikan. Pendidikan di Indonesia dilaksanakan dalam rangka mencerdaskan dan meniangkatkan kualitas manusia yang beriman dan bertaqwa kepada 
Tuhan Yang Maha Esa sebagaimana tercantum dalam Undang-Undang Pendidiakn No. 20 tahun 2003 tentang Sistem pendidikan nasional pasal 3, dinyatakan bahwa:

Pendidikan nasional berfungsi mengembangkan kemampuan dan membentuk watak serta peradaban bangsa yang bermartabat dalam rangka mencerdaskan kehidupan bangsa, bertujuan untuk berkembangnya potensi peserta didik agar menjadi manusia yang beriman dan bertaqwa kepada Tuhan Yang Maha Esa, berakhlak mulia sehat, cakap, kreatif, mandiri dan menjadi warga negara yang demokrasi serta bertanggung jawab.

Salah satu cara merealisasikan tujuan pendidikan nasional tersebut adalah melalui proses belajar mengajar, dengan cara ini di- harapkan anak dapat menggali ilmu pengetahuan sebanyak-banyaknya agar mampu berperan aktif di tengah-tengah kehidupan masyarakat yang mampu mengikuti perkembangan zaman. Dengan demikian seseorang mendapatkan kedudukan yang mulia di tengah-tengah manusia dan di sisi Allah SWT sebagaimana firman Allah SWT dalam Al-Qur'an Surah Al-Mujadalah ayat 11 yang berbunyi:

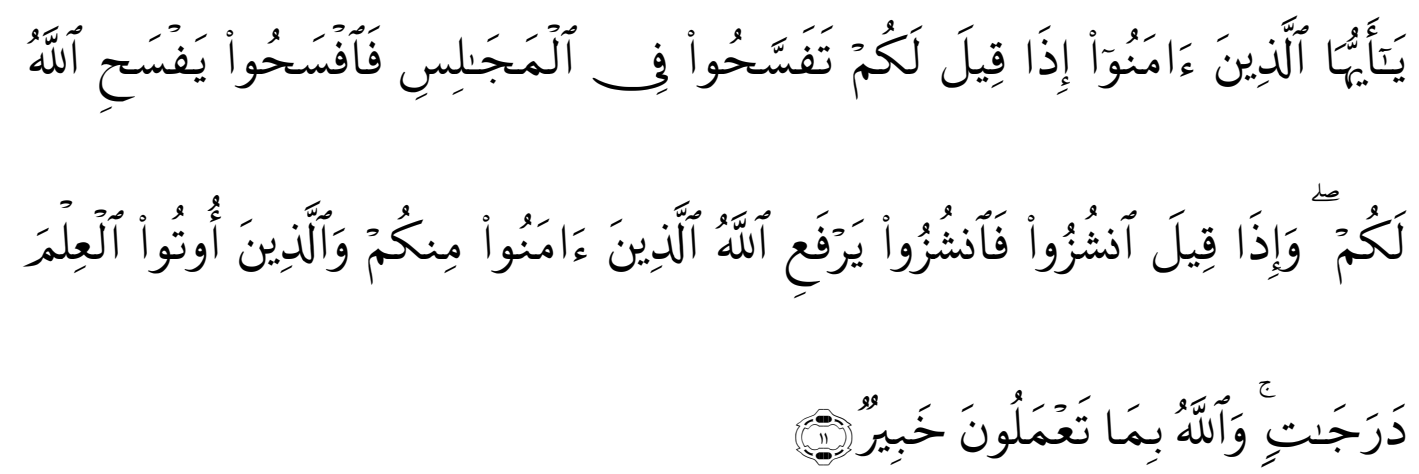

Artinya : Hai orang-orang beriman apabila kamu dikatakan kepadamu: "Berlapang-lapanglah dalam majlis", Maka lapangkanlah niscaya Allah akan memberi kelapangan untukmu. dan apabila dikatakan: "Berdirilah kamu", Maka berdirilah, niscaya Allah akan meninggikan orang-orang yang beriman di antaramu dan orang-orang yang diberi ilmu pengetahuan beberapa derajat. dan Allah Maha mengetahui apa yang kamu kerjakan. 
Ayat di atas menerangkan bahwa pengesaan dan pemahaman terhadap ilmu pengetahuan merupakan faktor yang sangat penting untuk mencapai kemajuan dalam diri seorang, maka semakin jelas bahwa orang yang memiliki ilmu pengetahuan derajatnya lebih tinggi dari orang yang tidak memiliki ilmu pengetahuan. Karena itu umat Islam dianjurkan untuk menuntut ilmu pengetahuan, baik yang umum ataupun agama yang bersumber dari Al-Qur'an dan hadist.

\section{LANDASANTEORI}

\section{Pengertian Pendidikan Islam}

Bila mana pendidikan kita artikan sebagai latihan mental, moral dan fisik (jasmaniah) yang menghasilkan manusia berbudaya tinggi untuk melaksanakan tugas kewajiban dan tanggung jawab dalam masyarakat selaku hamba Allah, maka pendidikan berarti menumbuhkan personalitas (kepribadian) serta menanamkan rasa tanggung jawab, usaha kependidikan bagi manusia menyerupai makanan yang berfungsi memberikan vitamin bagi pertumbuhan manusia.

Tujuan dan sasaran pendidikan berbeda-beda menurut pandangan hidup masing-masing pendidik atau lembaga pendidikan. Oleh karena itu perlu dirumuskan pandangan hidup Islam yang mengarahkan tujuan dan sasaran pendidikan Islam.

Sebagai landasan pandangan seorang muslim disebutkan dalam ayat Al-Qur'an QS. Ali Imran ayat 19

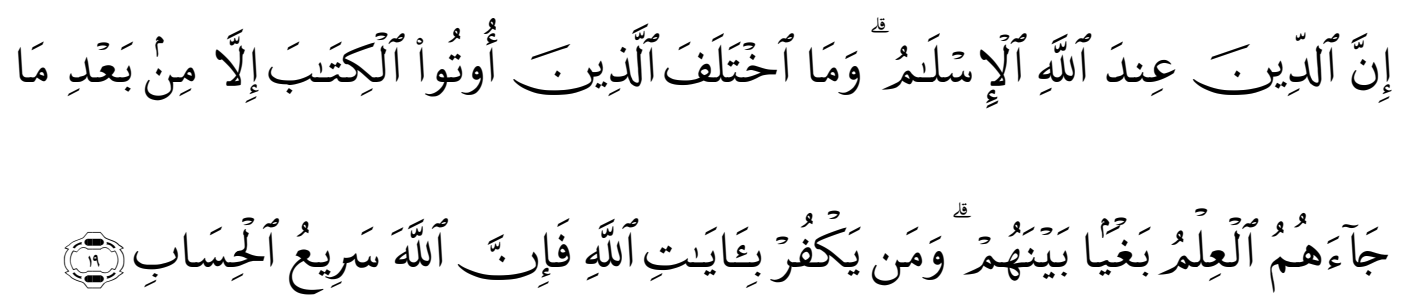

19. Sesungguhnya agama (yang diridhai) disisi Allah hanyalah Islam. tiada berselisih orang-orang yang telah diberi Al Kitab[189] kecuali sesudah datang pengetahuan kepada mereka, karena kedengkian (yang ada) di antara mereka. Barangsiapa yang kafir terhadap ayat-ayat Allah Maka Sesungguhnya Allah sangat cepat hisab-Nya. 
[189] Maksudnya ialah Kitab-Kitab yang diturunkan sebelum Al Quran.

Oleh karena itu, bila manusia yang berpredikat muslim, benar-benar menjadi penganut agama yang baik ia harus mentaati ajaran Islam dan menjaga agar rahmat Allah tetap berada pada dirinya. Ia harus mampu memahami, menghayati dan mengamalkan ajarannya yang didorong oleh iman sesuai dengan akidah Islamiah.

Untuk tujuan itulah manusia harus dididik melalui proses pendidikan Islam. Berdasarkan pandangan diatas, maka pendidikan Islam adalah sistem pendidikan yang dapat memberikan kemampuan seseorang untuk memimpin kehidupannya sesuai dengan cita-cita Islam, karena nilai-nilai Islam telah menjiwai dan mewarnai corak kepribadiannya.

Amat banyak pengertian Pendidikan Islam yang telah dikemukakan oleh para pakar pendidikan Islam. Ahmad D. Marimba menyatakan bahwa pendidikan Islam adalah bimbingan jasmani dan rohani berdasarkan hukum-hukum agama Islam menuju terbentuknya kepribadian utama menurut ukuran-ukuran Islam. Dengan pengertian lain, seringkali beliau menyatakan kepribadian utama dengan istilah kepribadian muslim yaitu kepribadian yang memiliki nilai-nilai agam aIslam, memilih dan memutuskan serta berbuat berdasarkan nilai-nilai Islam dan bertanggung jawab sesuai dengan nilai-nilai Islam.

Menurut Burlian Somad, Pendidikan Islam adalah pendidikan yang bertujuan membentuk individu menjadi makhluk yang bercorak diri, berderajat tinggi menurut ukuran Allah dan isi pendidikannya adalah mewujudkan tujuan itu, yaitu ajaran Allah. Secara terperinci, beliau mengemukakan, "Pendidikan itu disebut pendidikan Islam apabila memiliki dua ciri khas, yaitu tujuannya membentuk individu menjadi bercorak diri tertinggi menurut ukuran Al-Qur'an dan isi pendidikannya adalah ajaran Allah yang tercantum dengan lengkap di dalam AlQur'an yang pelaksanaannya di dalam praktek hidup sehari-hari sebagaimana yang dicontohkan oleh Nabi Muhammad SAW.

Menurut Syekh Muhammad An-Naquib Al-Attas, Pendidikan Islam adalah usaha yang dilakukan pendidik terhadap anak didik untuk pengenalan dan pengakuan tempat-tempat yang benar dari segala sesuatu di dalam tatanan 
penciptaan sehingga membimbing ke arah pengenalan dan pengakuan akan tempat Tuhan yang tepat di dalam tatanan wujud dan keberadaan.

Musthafa Al-Ghulayaini memberikan pengertian Pendidikan Islam yaitu menanamkan akhlak mulai di dalam jiwa anak dalam masa pertumbuhannya dan menyiraminya dengan air petunjuk dan nasihat, sehingga akhlak itu menjadi salah satu kemampuan (meresap dalam) jiwanya, kemudian buahnya berwujud keutamaan, kebaikan dan cinta bekerja untuk memanfaatkan tanah air.

\section{Dasar-Dasar Pendidikan Islam}

Dasar adalah landasan tempat berpijak atau tegaknya sesuatu agar sesuatu tersebut tegak kokoh berdiri. Dasar suatu bangunan yaitu fondamen yang menjadi landasan bangunan tersebut agar bangunan itu tegak dan kokoh berdiri. Demikian pula dasar pendidikan Islam yaitu fondamen yang menjadi landasan atau asas agar pendidikan Islam dapat tegak berdiri tidak mudah roboh karena tiupan angin kencang berupa ideologi yang muncul baik sekarang maupun yang akan datang. Dengan adanya dasar ini, maka pendidikan Islam akan tegak berdiri dan tidak mudah diombangambingkan oleh pengaruh luar yang mau merobohkan ataupun mempengaruhinya.

Pembahasan tentang dasar pendidikan Islam tidak dapat dipisahkan dari Islam dengan segala ajarannya, ajaran itu bersumber pada Al-Qur'an Sunnah Rasulullah SAW dan rakyu (hasil fikir manusia). Tiga sumber itu harus digunakan secara hirarkis. Al-Qur'an harus didahului apabila suatu ajaran atau penjelasannya tidak ditemukan di dalam Al-Qur'an, maka harus dicari di dalam sunnah, apabila tidak juga ditemukan di dalam sunnah, barulah digunakan rakyu, sunnah tidask dapat bertentangan dengan Al- Qur'an dan Rakyu tidak boleh bertentangan dengan Al-Qur'an dan Sunnah.

Menurut Hery Noer Aly, MA dalam buku beliau "Ilmu Pendidikan Islam, Dasar Pendidikan Islam secara garis besar ada 3 yaitu: Al-Qur'an, As-Sunnah dan Ra'yu.

\section{a. Al-Qur'an}

Islam adalah agama yang membawa misi agar umatnya menyelenggarakan 
pendidikan dan pengajaran. Ayat Al-Qur'an yang pertama kali turun adalah berkenaan disamping masalah keimanan juga pendidikan

Bahkan tidak hanyaitu Allah juga memberikan bahan (materi pendidikan agar manusia hidup sempurna di dunia ini).

Allah berfirman dalam al-Qur' an QS al-Baqarah ayat 31 :

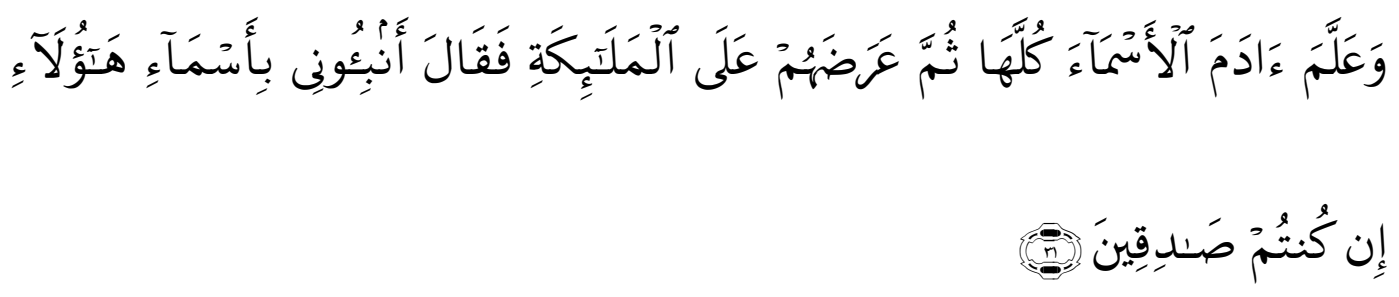

Artinya : Dan Dia mengajarkan kepada Adam Nama-nama (benda-benda) seluruhnya, kemudian mengemukakannya kepada Para Malaikat lalu berfirman: "Sebutkanlah kepada-Ku nama benda-benda itu jika kamu mamang benar orangorang yang benar!"

Ayat ini menjelaskan bahwa untuk memahami segala sesuatu belum cukup kalau hanya memahami apa, bagaimana serta manfaat benda itu tetapi harus memahami sampai ke hakikat dari benda itu.

Al-Qur'an, dalam penegasan Allah dan keyakinan kaum muslimin, merupakan sumber pertama ajaran-ajaran dasar Islam. Sebagai ajaran yang datang dari Allah Yang Maha Besar, kebenarannya bersifat mutlak dan kekal. Oleh sebab itu, sikap keagamaan yang mukmin terhadap Al-Qur'an adalah memahami kebenaran pernyataannya dengan bertitik tolak dari keyakinan, bukan memandangnya sebagai bahan baku teori, hipotesis atau asumsi ilmiah yang memerlukan pembuktian dengan bertitik tolak dari keraguan.

\section{b. As-Sunnah}

Al-Qur'an disampaikan oleh Rasulullah SAW. kepada umat manusia dengan penuh amanah, tidak sedikit pun ditambah atau pun dikurangi. Selanjutnya, manusialah yang hendaknya berusaha memahaminya, kemudian mengamalkannya.

Sering kali manusia menemui kesulitan dalam memahaminya, dan ini dialami oleh para sahabat sebagai generasi pertama penerima Al-Qur'an. Karenanya, 
mereka meminta penjelasan kepada Rasulullah SAW.

Penjelasan tersebut disebut Al-Sunnah yang secara bahasa berarti Al-Thariqah, jalan dan dalam hubungan dengan Rasulullah SAW berarti segala perkataan, perbuatan atau ketetapannya.

Para ulama menyatakan bahwa kedudukan Sunnah terhadap Al-Qur'an adalah sebagai penjelas. Bahkan, Umar bin Khatab seperti yang dikutip oleh Hery Noer Aly menginginkan bahwa Sunnah merupakan penjelas yang paling baik. Ia berkata, "Akan datang suatu kaum yang membantahmu dengan hal-hal yang syubhat di dalam Al-Qur'an. Maka hadapilah mereka dengan berpegang kepada sunnah, karena orang-orang yang bergelut dengan Sunnah lebih tahu tentang kitab Allah.”

\section{c. Ra'yu}

Masyarakat selalu mengalami perubahan, baik mengenai nilai-nilai sosial, kaidahkaidah sosial, pola-pola tingkah laku, organisasi, susunan lembaga-lembaga kemasyarakatan, lapisan-lapisan dalam masyarakat, kekuasaan dan wewenang, maupun interaksi sosial, dan lain sebagainya.

Pendidikan Islam sebagai lembaga sosial akan turut mengalami perubahan sesuai dengan perubahan yang terjadi di dalam masyarakat.

Perubahan-perubahan seperti dikemu- kakan di atas dan munculnya gagasangagasan baru tentang pendidikan pada gilirannya melahirkan berbagai masalah pendidikan. Apakah perubahan yang terjadi bertentangan dengan nilai-nilai hakiki pendidikan ataukah malah sebaliknya, meningkatkannya?

\section{Ruang Lingkup Ilmu Pendidikan Islam}

Pendidikan Islam sebagai ilmu, mempunyai ruang lingkup yang sangat luas, karena di dalamnya banyak segi-segi atau pihak-pihak yang ikut terlibat baik langsung atau tidak langsung.

Adapun segi-segi dan pihak-pihak yang terlibat dalam pendidikan Islam sekaligus menjadi ruang lingkup pendidikan Islam adalah sebagai berikut:

1. Perbuatan mendidik itu sendiri

2. Anak didik 
3. Dasar dan Tujuan Pendidikan Islam

4. Pendidik

5. Materi Pendidikan Islam

6. Metode Pendidikan Islam

7. Evaluasi Pendidikan

8. Alat-Alat Pendidikan Islam

9. Lingkungan Sekitar atau Millieu Pendidikan Islam

\section{Karakteristik Pendidikan Islam}

Adapun yang menjadi karakteristik Pendidikan Islam adalah sebagai berikut:

1. Pendidikan Islam selalu mempertimbangkan dua sisi kehidupan duniawi dan ukhrawi dalam setiap langkah dan geraknya.

2. Pendidikan Islam merujuk pada aturanaturan yang sudah pasti

3. Pendidikan Islam bermisikan pembentukan akhlakul karimah

4. Pendidikan Islam diyakini sebagai tugas suci dan bermotifkan ibadah

\section{Tujuan Pendidikan Islam}

Tujuan yaitu sasaran yang akan dicapai oleh seseorang atau kelompok orang yang melakukan suatu kegiatan. Karena itu tujuan pendidikan Islam, yaitu sasaran yang akan dicapai oleh seseorang atau sekelompok orang yang melaksanakan pendidikan Islam.

Menurut Ahmad D. Marimba, fungsi tujuan itu ada empat macam, yaitu:

a. Mengakhiri usaha

b. Mengarahkan usaha

c. Tujuan merupakan titik pangkal untuk mencapai tujuan-tujuan lain, baik merupakan tujuan-tujuan baru maupun tujuan tujuan lanjutan dari tujuan pertama

d. Memberi nilai (sifat) pada usaha-usaha itu.

\section{Kegunaan Ilmu Pendidikan Islam}

Ilmu Pendidikan Islam memiliki arti dan peranan penting dalam kehidupan. Hal tersebut disebabkan Ilmu Pendidikan Islam memiliki fungsi sebagai berikut: 
a. Ia melakukan pembuktian terhadap teori-teori kependidikan Islam yang merangkum aspirasi atau cita-cita Islam yang harus diikhtisarkan agar menjadi kenyataan.

b. Ia memberikan bahan-bahan informasi tentang pelaksanaan pendidikan dalam segala aspeknya bagi pengembangan ilmu pengetahuan pendidikan Islam tersebut. Ia memberikan bahan masukan yang berharga (input) kepada ilmu ini. Mekanisme proses kependidikan Islam dari segi operasional dapat dipersamakan dengan proses mekanisme yang berasal dari penerimaan input (bahan masukan), lalu diproses dalam kegiatan pendidikan (dalam bentuk kelembagaan atau non kelembagaan yang disebut truput), kemudian berakhir pada output (hasil yang diharapkan).

c. Disamping itu juga menjadi pengoreksi (korektor terhadap kekurangan. Teoriteori yang terdapat dalam ilmu pendidikan Islam itu sendiri, sehingga kemungkinan pertemuan antara teori dan praktek semakin dekat dan hubungan antara keduanya semakin bersifat interaktif(saling mempengaruhi).

\section{METODE PENELITIAN}

Untuk memperoleh data-data yang dibutuhkan dalam penelitian ini, penulis menggunakan motode library research atau studi kepustakaan dalam arti semua sumber datanya berasal dari bahan tertulis, yakni penulis mempelajari dan menelaah bahan-bahan pustaka khususnya yang berkenaan dengan masalah konsep Pendidikan Islam Yang Terkandung Dalam Surah Al-A'raf Ayat 179, dan dalam penyusunan ini penulis menggunakan metode maudhu'i, yaitu memilih surah dan ayat yang berkaitan dengan penggunaan pancaindera dan hubungannya dengan pendidikan Islam. Langkah-langkah yang ditempuh dalam metode tematik ini meliputi: a) menetapkan masalah yang dibahas, b) menghimpun ayat-ayat yang berkaitan dengan maalah yang dibahas, c) memahami kolerasi ayat-ayat tersebut dalam surahnya masing- masing, d) melengkapi hubungan dengan hadis-hadis yang relevan. 


\section{HASIL PENELITIAN DAN PEMBAHASAN}

\section{Ma'na Mufradat Surah Al-A'araf Ayat 179}

Sebelum memaparkan tentanga tafsir surah Al-A'raf, berikut ini dicantumkan teks surah Al-A' araf ayat 179 sebagai berikut:
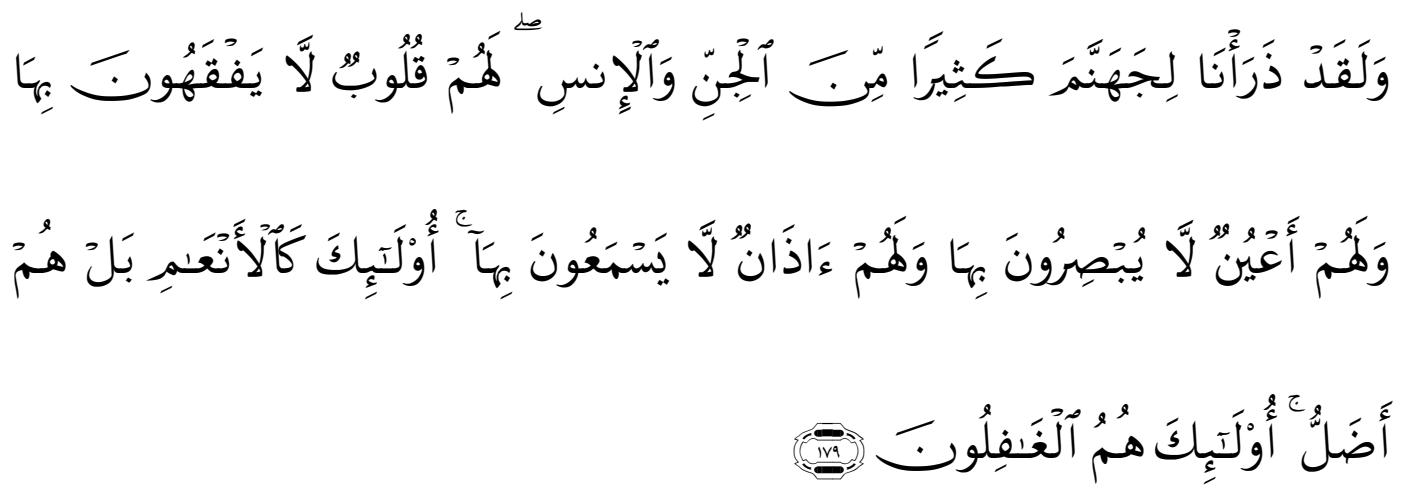

Artinya : Dan Sesungguhnya Kami jadikan untuk (isi neraka Jahannam) kebanyakan dari jin dan manusia, mereka mempunyai hati, tetapi tidak dipergunakannya untuk memahami (ayat-ayat Allah) dan mereka mempunyai mata (tetapi) tidak dipergunakannya untuk melihat (tanda-tanda kekuasaan Allah), dan mereka mempunyai telinga (tetapi) tidak dipergunakannya untuk mendengar (ayat-ayat Allah). mereka itu sebagai binatang ternak, bahkan mereka lebih sesat lagi. mereka Itulah orang-orang yang lalai.

Kata Az-Zar'u sama artinya dengan al-khalqu (menciptakan) bila orang berkata, zara'allahul khalqa, itu artinya Allah mengadakan individu-individu makhluk. Sedang arti al-khalqu itu sendiri. At-taqdir(mengukur), yakni mengadakan sesuatu dengan ukuran dan aturan tertentu, bukan ngawur.

Kata Al-Jinn berarti makhluk hidup berakal, dibebani syariat, tetapi tidak kelihatan, tak bisa diindera.

Kata al-Qalb, kadang-kadang diartikan segumpal daging berbentuk daun pinus, terletak disisi kiri dari tubuh manusia (jantung). Tapi kadang-kadang yang di- maksud adalah akal dan naluri kejiwaan, yang kadang-kadang disebut hati nurani (qamir). Disanalah terletak penilaian terhadap macam-macam pengertian, dan perasaan suka cita terhadap yang menyakitkan. Al-Qalb menurut arti yang kedua ini banyak terdapat dalam Al-Qur' an diantaranya: 
Adapun sebab dipakainya Al-Qalbu untuk arti yang kedua ini adalah karena orang melihat rasanya jantung itu bisa mengembang dan mengempis ketika dia merasa takut dan jijik, atau ketika merasa gembira dan senang.

\section{Tafsir Ijmali Surah Al-A'araf Ayat 179}

Jika diamati dengan seksama, surah Al-A'raf ayat 179 ini memuat materimateri pendidikan. Adapun materi-materi pendidikan Islam yang terdapat dalam surah Al-A'raf ayat 179 ini adalah:

a. Orang mukmin akan meningkat jiwanya Sebelum kita membahas hal ini, perlu kita ketahui bahwasannya ayat sebelumnya, yaitu ayat 178 mempunyai hubungan yang sangat erat dengan ayat 179 sebagaimana firman Allah:

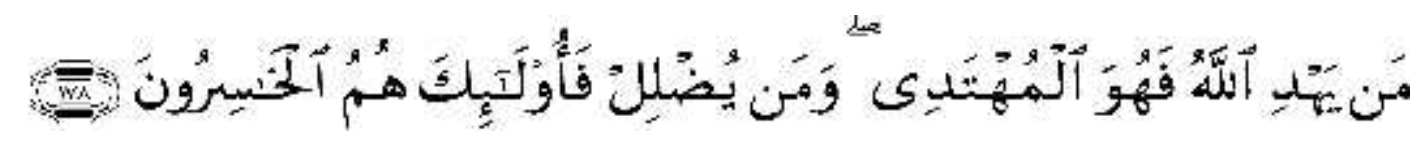

Siapa saja yang diberi taufik oleh Allah, hingga ia mau menempuh jalan yang benar, karena dia mau menggunakan akal dan inderanya dengan semestinya, sesuai dengan fitrah dan bimbingan agama, maka dialah orang yang benar-benar memperoleh petunjuk karena berarti dia bersyukur atas nikmat-nikmat yang dianugerahkan Allah kepadanya, dan menunaikan kewajiban yang dibebankan Allah kepadanya. Maka dialah yang bakal memperoleh kebahagiaan di dunia maupun diakhirat.

Kemudian Allah SWT. Menerangkan lebih detail apa yang masih mujmal, disamping diterangkan pula sebab masing-masing. Firman-Nya.

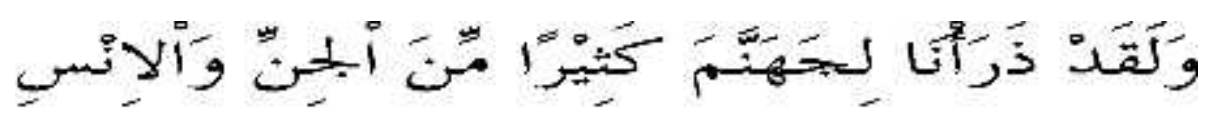

Kami bersumpah bahwa sesungguhnya kami telah menciptakan di dunia ini banyak sekali calon- calon penghuni neraka jahannam yang bakal tinggal disana, baik dari bangsa jin maupun manusia. Dan begitu pula Kami menciptakan caloncalon penghuni surga dengan keadilan masing-masing dari dua golongan itu.

Kemudian diterangkan pula oleh Allah apa sebab mereka menjadi calon penghuni jahannam dan apa sifat-sifat mereka sehingga patut dimasukkan ke 
sana. Firman- Nya;

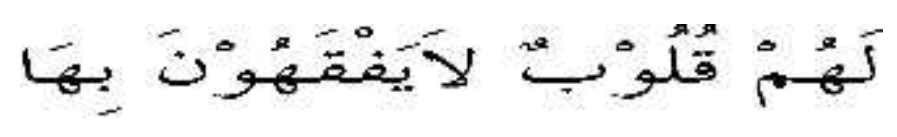

Sesungguhnya calon-calon penghuni jahannam itu sekalipun punya hati, tetapi tidak digunakan untuk memahami cara-cara mensucikan jiwa, seperti tauhid yang dapat menghindarkan jiwa dari khufarat dan dongeng-dongeng yang tak masuk akal dan menjauhkannya dari kehinaan dan kenistaan. Karena orang yang menyembah kepada Allah semata-mata, maka dengan mengenal Allah itu, dia akan meningkat jiwanya. Sehingga dia tak sudi menghinakan diri dengan berdoa dengan selain Allah, atau takut berharap dan bersandar kepadanya. Tetapi, hanya kepada Allahlah dia meminta apa yang dia perlukan. Kalau apa yang dihajatkan itu termasuk perkara yang Allah memberi kemampuan kepada makhluk- Nya untuk mencapainya, dengan memberitahu kepada mereka sebab-sebabnya dan memberi kemungkinan kepada mereka untuk menempuh sebab-sebab tersebut, maka dia tuntut hajatnya itu sesuai dengan sebab yang bisa mengantarkan dia kepadanya, di samping tetap memperhatikan sunnah-sunnah Allah pada makhluk-Nya.

b. Kaum Muslimin Lalai dalam Merenung- kan Ayat-ayat Allah

Dan demikianlah pula mereka mempunyai mata dan telinga, namun tidak mereka pergunakan untuk memperhatikan dan berpikir tentang tanda-tanda kebesaran Allah yang ada pada makhluk-Nya yang mereka lihat, atau tentang ayat-ayatNya yang diturunkan kepada rasul-rasul-Nya yang mereka dengar. Juga tentang kejadian-kejadian dalam sejarah yang menunjukkan kepada sunnah-sunnah Allah pada makhluk-Nya, sehingga mereka mendapat petunjuk dengan semua itu ke arah yang mengantarkan mereka kepada kebahagiaan mereka di dunia dan akhirat.

c. Islam Melarang Kikir dan Berlebihan

Orang-orang yang mempunyai sifat-sifat tersebut diatas, bagaikan binatang ternak, unta, lembu atau kambing. Karena akal yang ada pada mereka tak ada gunanya selain dipergunakan untuk hal-hal yang berkaitan dengan penghidupan duniawi belaka. Atau bahkan mereka lebih sesat lagi dari pada bintang ternak, karena binatang ternak itu sekalipun hidupnya hanya untuk memenuhi kebutuhan dirinya sendiri saja, namun mereka tepat tidak melamapui sunnah-sunnah fitrahnya 
dan batas-batas kebutuhannya yang wajar, baik dalam soal makan, minum dan dalam memenuhi segala kebutuhannya. Lain halnya budak-budak nafsu. Dalam segalagalanya mereka sangat berlebih-lebihan dan oleh karenanya sering timbul berbagai macam penyakit. Atau sebaliknya mereka memerangi syahwat-syahwat nafsurnya yang keterlaluan, sehingga menyepelekan hak-hak tubuhnya sendiri. Mereka tidak memberi makan secukupnya kepada tubuhnya itu atau tidak menunaikan kewajiban terhadap suami atau istrinya.

\section{Nilai-Nilai Pendidikan Islam Yang Terkandung Dalam Surah Al- A'raf Ayat 179}

Adapun yang menjadi nilai-nilai pendidikan Islam yang terkandung dalam surat Al-A'raf adalah neraka jahannam disediakan bagi Jin dan Manusia, orang yang mempunyai akal/otak, orang yang mempunyai mata, orang yang mempunyai telinga, diumpakan seperti bintang bahwa lebih buruk lagi.

a. Neraka Jahannam Disediakan Bagi Jin Dan Manusia, Pendidikan Tauhid atau Akidah

b. Pendidikan Fiqih

c. Pendidikan Tasauf

2. Orang yang mempunyai akal/otak,

Ahli hikmah mengatakan bahwa akal yang sehat terletak pada badan yang sehat.

Otak/akal manusia bisa saja menjadi ancaman atau melapataka ketika otak manusia tidak sehat. Kesehatan otak sangat berpengaruh terhadap fungsi akal manusia itu sendiri. Apabila otak manusia tidak sehat secara mintal maka manusia tidak berpikir secara logis (masuk akal) atau tidak berpikir secara runtun. Untuk itu perlu kiranya men- jaga kesehatan otak (akal) dengan disertai menjaga kesehatan anggota badan, agar dapat dimanfaatkan sebaik-baik dalam menuntut ilmu pengetahuan agama.

3. Orang yang mempunyai mata, 
a. Dengan mata kita bisa membaca Alquran, Hadis dan Kitab-Kitab Agama Islam.

b. Dengan mata manusia dapat membaca tanda-tanda kebesaran Allah pada Alam semesta.

c. Dengan mata manusia dapat membedakan berbagai jenis makhluk hidup yang diciptakan oleh Allah SWT.

4. Orang yang mempunyai telinga

5. Diumpakan seperti bintang bahkan lebih buruk lagi.

Manusia yang menggunakan anugerah yang diberikan oleh Allah berupa otak, mata dan telinga dengan sebaik-baik adalah manusia yang mensyukuri nikmat yang telah diberikan Allah kepadanya. Mensyukuri nikmat otak, mata dan telinga seperti digunakan untuk menggali ilmu pengetahuan agama dan melaksanakan ibadah kepadaAllah SWT.

Ada sebagian manusia yang memiliki hati tetapi tidak mereka gunakan untuk memahami, memiliki mata yang tidak mereka gunakan untuk melihat, dan memiliki telinga yang tidak mereka gunakan untuk mendengar. Yakni mereka tidak menfaatkan sedikitpun organ-organ tubuh yang telah diciptakan oleh Allah sebagai serana untuk memperoleh hidayah. Allah Ta'ala berfirman dalam surah Al-Hajj ayat 46 sebagai berikut:

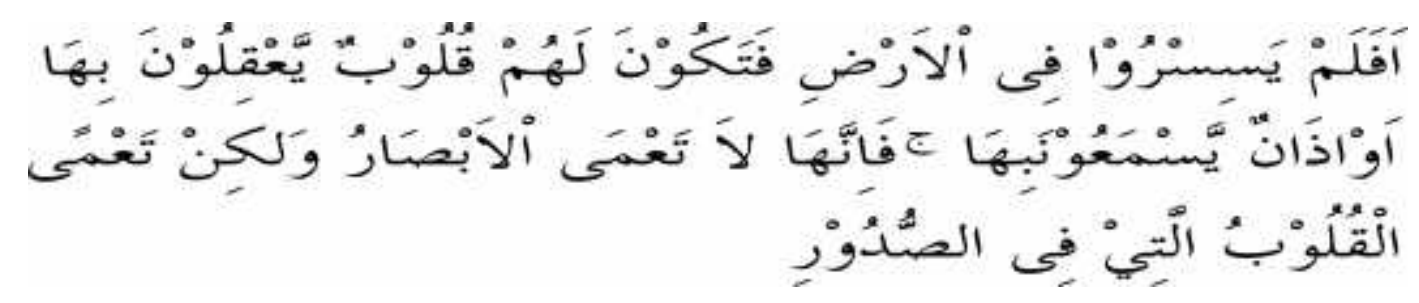

Mereka tidak tuli, tidak bisu, dan tidak buta kecuali terhadap hidayah. Hal ini seperti difirmankan Allah, "Karena sesungguhnya bukan mata itu yang buta, namun yang buta ialah hati di dalam dada. Mereka itu seperti binatang. "Yakni, orang- orang yang tidak menyimak kebenaran, tidak menyadarinya, dan tidak melihat hidayah adalah seperti binatang yang dilepas yang tidak memanfaatkan organ-organ tubuh itu kecuali sekedar untuk memperoleh makanan dalam kehidupan lahiriah dunia. Bintang itu mendengar suara pengembalanya namun 
ia tidak memahami apa yang diucapkan. Maka sehubungan dengan mereka Allah berfirman, "Bahkan mereka lebih sesat" dari pada binatang-bintang itu sebab binatang kadang-kadang dapat menuruti hardikan pengembala walaupun ia tidak memahaminya. Kemudian binatang itu berbuat menurut tujuan penciptaannya baik berdasarkan nalurinya maupun karena ketaklukannya. Hal itu berbeda dengan orang kafir. Sesungguhnya Allah menciptakan dia supaya menghambakaan diri kepada Allah dan mengesakan-Nya, lalu dia mengingkari dan menyakutukan Allah Ta'ala. Maka menusia yang taat kepada Allahh lebih mulia keadaannya di akhirat daripada malaikat, sedangkatn manusia yang kafirkepadaNya adalah lebih buruk dari pada binatang.

\section{KESIMPULAN}

Dalam Surah Al-A'raf ayat 179, Allah menjelaskan bahwasannya yang akan menjadi penghuni neraka adalah orang-orang lalai dan tidak mau menggunakan akal pikiran mereka untuk memahami hakikat dari segala sesuatu, tidak mau memanfaatkan mata dan telinga mereka baik untuk menyimpulkan segala yang diketahuinya dan mengambil ilmu-ilmu maupun untuk mengetahui tanda-tanda kebesaran Allah yang ada pada alam ciptaan-Nya, dan tanda-tanda kebesaran-Nya yang tertera dalam kitab-kitab-Nya yang kedua-duanya adalah merupakan sebab kesempurnaan iman dan menjadi dorongan jiwa untuk menyempurnakan Islam seseorang.

Nilai-nilai pendidikan Islam yang terkandung dalam surah Al-A'raf ayat 179 ini meliputi:
a. Neraka Jahannam Disediakan Bagi Jin Dan Manusia,
b. Orang yang mempunyai akal/otak,
c. Orang yang mempunyai mata,
d. Orang yang mempunyai telinga
e. Diumpakan seperti bintang bahkan lebih buruk lagi. 


\section{DAFTAR PUSTAKA}

Abuddin Nata, Metodologi Studi Islam, (Jakarta: Raja Grafindo Persada, 2000).

Abdul Hamid Al-Hasyimi, Mendidik Ala Rasulullah, (Jakarta: Terjemah Ibnu Ibrahim, Pustaka Azzam, 2001).

Abdurrahman Saleh Abdullah, Teori-Teori Pendidikan Berdasarkan AlQur'an, (Jakarta: Rineka Cipta, 2005)

Ahmad D. Marimba, Pengantar Filsafat Pendidikan Islam, (Bandung: AlMa'arif, 1987).

Ahmad Mustafa Al-Maraghi, Tafsir Al-Maraghi Juz 9, Penerjemah Bahrun Abu Bakar, (Semarang: Thoha Putra, 1993)

Departemen Agama RI. Al-Qur'an dan Terjemahnya. Penerjemah Yayasan/ Pentafsir Al-Qur'an, (Bandung: Jumanatul Ali, 2005).

Ngalimun. Pedoman Penulisan Karya Ilmiah, (Yogyakarta: KMedia, 2014)

Sayyid Quthb, Tafsir Fi Zhilalil Qur'an, (Jakarta: Gema Insani Press, 2003)

Soleh M. Basalamah, Pengantar Ilmu Al- Qur'an, (Semarang: Thoha Putra, 1997)

Syekh Muhammad Nawawi Al-Bantani, Al Jawi Asy-Syafi'i Al-Qadiri, Bahjatul Wasail, (Semarang: Ar Ridha, 1994)

Suwendi, Sejarah dan Pemikiran Pendidikan Islam, (Jakarta: Raja Grafindo Persada, 2004). 